\title{
Introduction: Studying Under-Floor Church Burials in Finland-Challenges in Stewarding the Past for the Future
}

\author{
Sanna Lipkin (D) Titta Kallio-Seppä
}

Accepted: 10 July 2020 /Published online: 19 October 2020

(C) The Author(s) 2020

\begin{abstract}
Two ongoing projects at the University of Oulu, Finland, are studying burials situated below the floorboards of Finnish churches. The projects examine mortality and materiality in Finland using an exceptionally well-preserved assemblage of mummified human remains. Multidisciplinary research methods, including CT scanning, $\mu \mathrm{CT}$ scanning, sampling for DNA and isotope analysis, and insect and plant samples, are providing multifaceted information concerning past societies. The samples provide rich insight into the material dimensions of mortality in northern Europe in the 18th and 19th centuries. Since the studied material is located under the floors of church buildings that are still in use by congregations, obtaining permits for research and sampling has required managing relationships with separate parishes. This article outlines the projects and examines the ethical and legal dimensions of research on human remains conducted in partnership with individual parishes.
\end{abstract}

Extracto En dos proyectos en curso en la Universidad de Oulu, Finlandia, se estudian los entierros situados debajo del piso de las iglesias finlandesas. En los proyectos se examinan la mortalidad y la materialidad en Finlandia utilizando un conjunto excepcionalmente bien conservado de restos humanos momificados. Los métodos de investigación multidisciplinarios, que

S. Lipkin $(\bowtie) \cdot$ T. Kallio-Seppä

Department of Archaeology, University of Oulu, Pentti Kaiteran katu 1, Linnanmaa, PL 8000, FI-90014 Oulu, Finland

e-mail: sanna.lipkin@oulu.fi incluyen la exploración por TC, la exploración por $\mu \mathrm{TC}$, el muestreo para análisis de isótopos y ADN y muestras de insectos y plantas, están proporcionando información polifacética sobre sociedades pasadas. Las muestras proporcionan una rica visión de las dimensiones materiales de la mortalidad en el norte de Europa en los siglos XVIII y XIX. Dado que el material estudiado se encuentra debajo de los pisos de los edificios de las iglesias que todavía están en uso por las congregaciones, la obtención de permisos para la investigación y el muestreo ha requerido la gestión de relaciones con parroquias separadas. Este documento describe los proyectos y examina las dimensiones éticas y legales de la investigación sobre restos humanos realizada en asociación con parroquias individuales.

Résumé Deux projets en cours à l'Université d'Oulu en Finlande se consacrent à l'étude de tombes situées sous les sols d'églises finlandaises. Les projets s'intéressent à la mortalité et à la matérialité en Finlande en s'appuyant sur un ensemble de restes humains momifiés exceptionnellement bien préservés. Des méthodes multidisciplinaires de recherche, notamment la tomodensitométrie $(\mathrm{CT})$, la microtomographie à rayons $\mathrm{X}(\mu \mathrm{CT})$, l'échantillonnage d'ADN et l'analyse d'isotope ainsi que des échantillons d'insectes et de plantes, fournissent des informations aux multiples facettes concernant les sociétés du passé. Les échantillons apportent de riches contributions quant aux dimensions matérielles de la mortalité dans l'Europe septentrionale au 18 ème comme au 19ème siècle. Le matériel étudié se trouvant sous les sols de bâtisses d'églises qui sont 
encore utilisées par les congrégations, l'obtention d'autorisations de recherche et d'échantillonnage a impliqué une gestion des relations avec les différentes paroisses. Cet article est un exposé de ces projets et il s'intéresse aux dimensions éthiques et juridiques de la recherche sur des restes humains conduite dans le cadre d'un partenariat avec des paroisses individuelles.

Keywords under-floor church burials · mummies · CT scanning $\cdot$ research ethics

\section{Introduction}

Burying the deceased under church floors was a common practice in Finnish churches from the medieval period until the latter half of the 18th century, when the tradition gradually ended in individual parishes. During the 18th century the tradition had become so popular that, at times, the space below the floorboards was filled with coffins stacked in burial chambers made of logs, stones, and bricks, or just left lying on the subsoil. A combination of frost and dry, wellventilated spaces beneath the church floors has resulted in mummification of many individuals in their coffins and exceptional preservation of organic materials, such as wooden coffins, textiles, and plant-based coffin bedding. Recently, researchers at the University of Oulu (Finland) created an extensive interdisciplinary research project related to the under-floor church burials. This has evolved into two individual projects: the Church, Space and Memory Project and the New Perspectives on Childhood in Finland (1600-1900): Funerary Attire as an Indicator of Status of Children Project. The articles of this thematic collection were originally presented in the session: "Mummified Human Remains from Early Modern Period to Present" at the 2017 Society for Historical Archaeology conference in Fort Worth, Texas, where scholars from both projects presented their latest research results. There is a broad range of archaeological scholarship on postmedieval death and burial (Veit and Brooks 2011; Tarlow and Nilsson Stuzt 2013; Tarlow 2015; Renshaw and Powers 2016; Mytum and Burgess 2018), but this thematic collection offers a range of new perspectives to research on historical mummified human remains (Mytum, this issue).

Research articles in this thematic collection provide examples of seamless interdisciplinarity where natural scientific methods have produced meaningful cultural and social knowledge of past human beings. For instance, microscopic examination of textiles, plant remains, and parasites has turned out to be important in understanding the social and cultural phenomena of humans and funerary practices. Fiber and textilestructure analysis have revealed that northern Finnish clergy were dressed in imported high-status funerary clothing (Väre et al., this issue), and textiles found in children's burials are generally of better quality and more varied than those in adults' burials, implying their special status in the society (Lipkin, Niinimäki et al., this issue). Furthermore, identification of a wide variety of plant remains uncovered the materials for mattresses and pillows used for the bedding in the coffins (Lipkin, Ruhl et al., this issue) and the herbs that were used to cover disgusting odors emanating from the rotting corpses (Kallio-Seppä and Tranberg, this issue). Additionally, the presence of certain insects in the burials may reveal the season of the burial (Lipkin, Ruhl et al., this issue), and parasitic illnesses are known to have had both historical and cultural significance for the population (Pye, this issue).

\section{Finnish Funerary Practices after the Reformation}

In Finland, exceptionally well-preserved under-floor church burials offer numerous possibilities for answering questions related to taphonomy, health and nutrition, and the cultural and social aspects of funerary customs. During the time of the church burials present-day Finland had long been an integral part of Sweden, constituting its eastern province (Karonen 1999; Villstrand 2009). Swedish laws also regulated Finnish lands. The church represented not just a public space, but also an institutional place, meaning that the church had administrative tasks, and it represented the order of the community and the power of the authorities. The power of the Swedish state was exercised through the church (Parland-von Essen 2010:27). The Reformation brought material changes to the churches during the 16th and 17 th centuries. Although the worship of the saints was forbidden, existing sculptures remained inside the church halls. Valuable metal items, such as thuribles, monstrances, and, from some parishes, the church bells, were collected from the churches and given to the Crown. During the 17th century, state control became tighter as the Crown took a hand in many aspects of life through church regulations (Hiekkanen 2003:170-172; 
Laitinen 2016:221-226). One of these regulations was the renewed Swedish Church Law that came into effect in 1686 (Hellemaa et al. 1986:18.8) and codified the relationship between the state and the Swedish Lutheran Church. The ruler of the Swedish state assumed supremacy in the church as church and state became one (Laasonen 1991:199-200; Laitinen 2016:227; Salonen 2016).

Burials were conducted both inside the churches and around them in graveyards. The church as a burial place was more valued until the middle of the 18th century, and everyone who could afford to be buried inside the churches was buried there. The best spaces were close to the altar where the wealthiest and highest-status families owned the burial chambers. Priests and their families were buried just below the altar (Paavola 1998:36). Inside the chambers, coffins were stacked in three to four layers. The 1686 Swedish Church Law specified that the coffins inside the church had to be buried to ca. $178 \mathrm{~cm}$ (70 in.) and covered with soil (Hellemaa et al. 1986:18.8.32). Research beneath the floors has proved that this code was rarely followed because many coffins are still uncovered, and most of them are only $0.5-1 \mathrm{~m}(1.7-3.3 \mathrm{ft}$.) under the floor planks. The coffins were furnished as beds, with white fabrics, and the funerary attire was constructed from old clothing items or reused fabrics folded, stitched, and pinned together to represent contemporary clothing.

In Swedish society, class differences were believed to be created by God and were as important in life as in death. Excessive consumption was regulated by sumptuary laws that also regulated funerary attire and coffins (Modée 1774:7142-7147). An individual's class was visible in both burial location and funerary attire, but the material suggests that sumptuary rules were not always followed. Funerary practice followed longstanding traditions and common religious conceptions; for instance, in the case of children's burials, families' emotions may be interpreted based upon the patterns by which they socialized their children (Lipkin, Niinimäki et al., this issue). However, a certain level of individuality is shown in, for example, the style of coffins and choices of textiles and decorations the families made when dressing the deceased for the funeral. The funerary materials describe the ideas and choices of rising modernity. More open attitudes during the time called the "Age of Liberty" (1718-1772) gave openings for new movements in Sweden and Finland, such as pietism, which considered faith to be a private, individual matter. Perceptions of the human body changed so that the corpse was treated as an individual and the grave as a social medium, instead of the corpse being treated collectively, wrapped in shroud, and laid in a coffin awaiting resurrection (Karonen 1999; Tarlow 2002; Tagesson 2015; Cherryson 2018). For example, writing the name of the deceased inside the coffin lid, on the coffin plates, or on pieces of paper placed on the deceased inside the coffin suggests that human beings were considered as individuals at the time of burial.

After the Finnish War in 1808-1809, Finland became part of the Russian Empire as the autonomous Grand Duchy of Finland. This did not cause major changes in the status of the church. The Russian czar ratified the religion and the constitution, and the Church Law remained in force. The czar continued as the supreme head of the Finnish Lutheran Church even though he was of the Orthodox faith (Murtorinne 1992:11; Meinander 2010:109-110).

In 1822 the czar gave an imperial order to end the church burial tradition and seal the old burial chambers (Paavola 1998:43). Already in 1786 the Swedish ruler had warned of the problems of the tradition and had strongly advocated separate graveyards outside the residential areas (Modée 1803:349-351). This led to gradual abandonment of the tradition in individual parishes.

\section{Northern Finnish Funerary Archaeological Research}

The roots of the research conducted at the University of Oulu go back to the 1990s when a few church sites were excavated and the first under-floor church inventories documenting the deceased by photographs and visual observation were undertaken by archaeologists, which resulted in a doctoral dissertation by Kirsti Paavola (1998; Núñez et al. 2011). Thereafter, the growing interest towards funerary research evolved through rescue excavations conducted at Oulu Cathedral churchyard (1996 and 2002) as well as collaboration with Oulu University Hospital and radiologist Jaakko Niinimäki (M.D.) to computed-tomography (CT) scan the remains of northern Finnish vicar Nikolaus Rungius (ca. 15601629), who is buried at St. Michael's Church at Keminmaa (Väre et al., this issue). The CT-scanned material of Vicar Rungius served as the basis for a reconstructed virtual 3-D model of his remains. This collaboration with the Oulu University Hospital has continued ever since, and seven more infant coffins have 
been CT scanned: four from Keminmaa (Lipkin, Niinimäki et al., this issue) and three from Haukipudas.

The funerary material examined within the two projects includes approximately 200 child burials and 500 adult burials dating primarily from the late 17 th century to the early 19th century. The material originates from archaeological excavations in churchyards in Ii, Oulu, and Rauma; excavations within both ruined and standing churches at Hailuoto, Köyliö, and Valmarinniemi; and documentation of coffins under church floors in Haukipudas, Keminmaa (Fig. 1), and Tornio in northern Ostrobothnia and southwest Finland.

The Church, Space and Memory Project seeks to determine how the meanings of northern Finnish religious spaces changed from the medieval period through the 19th century. The actions, experiences, traditions, and beliefs of the local people created social memory related to the churches and revealed how community members who had passed away were treated during burial and remembered afterwards. The project investigates how the community, the conceptions of the world, and changes in the community and worldview are visible in the religious spaces, traditions, and material culture of the churches and the burials. For instance, the project produced an osteobiography and life story for the mummified remains of Vicar Rungius, which have been a famous tourist attraction for decades (Väre et al., this issue). The Church, Space and Memory Project gathers together researchers from different fields of archaeology: bioarchaeology, paleopathology, childhood archaeology, entomology, and textile archaeology. This interdisciplinary approach offers a wide variety of approaches to investigating the cultural and material heritage preserved in Finnish churches and, especially, under their floors.
Fig. 1 Under-floor church burials in Keminmaa. (Photo by T. Kallio-Seppä, 2014.)

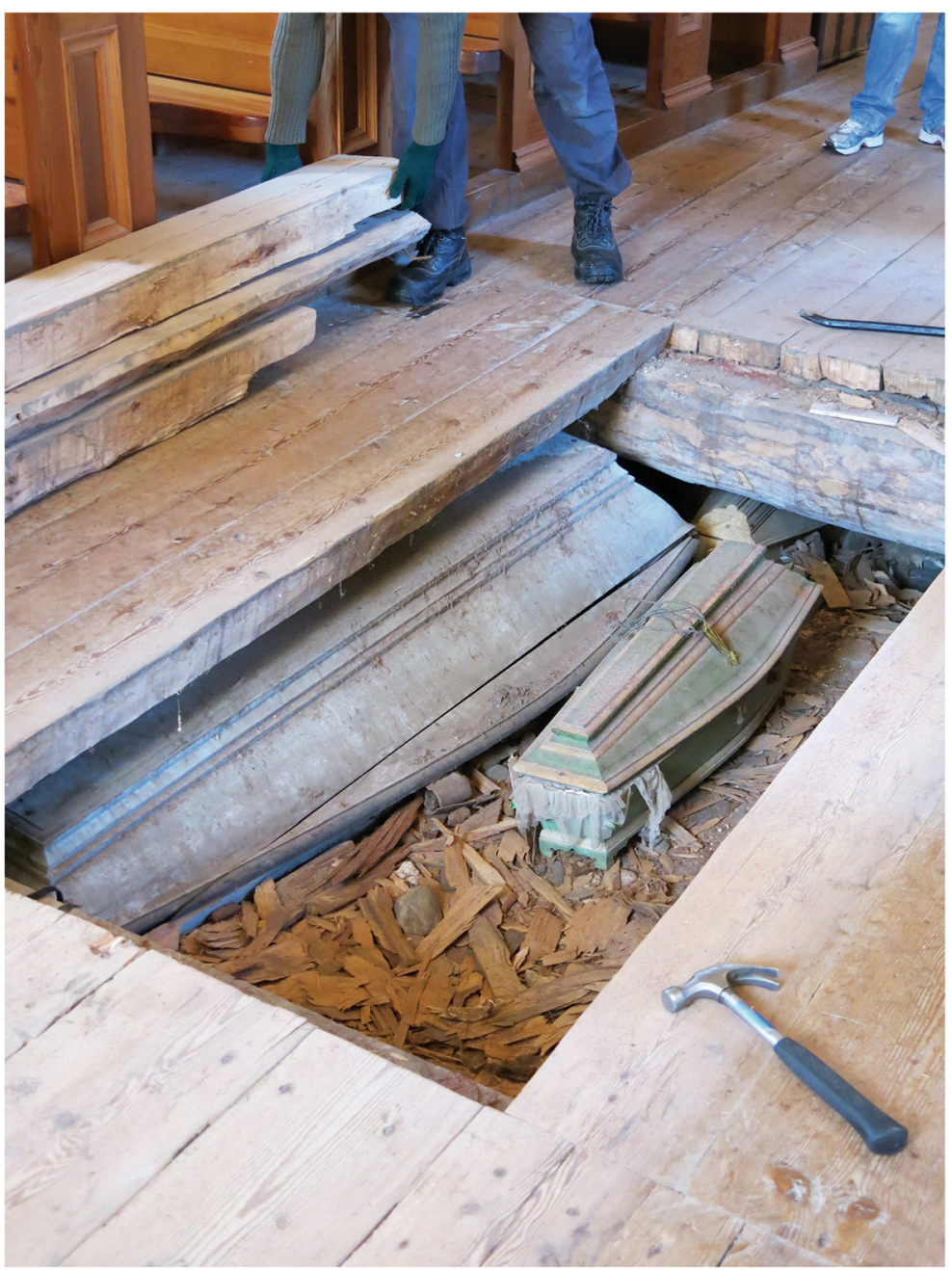


Among the under-floor church materials in particular, mummified child burials are very common. This is partially due to traditions related to church burial customs (Lipkin, Ruhl et al., this issue), but it also reflects children's historically high mortality rates. Until the late 19th century, approximately $40 \%$ of children in Finland died before the age of four (Turpeinen 1979:table 1). The project New Perspectives on Childhood in Finland (1600-1900): Funerary Attire as an Indicator of Status of Children has studied the emotions of parents, siblings, and other relatives toward dead children and how these emotions are visible in the coffins and funerary attire. The project studies both adults' attempts to socialize their children and the worldviews and actions of the children themselves in order to understand the contradiction between these two actively performing groups. Relationships are further studied by tracing postmedieval breastfeeding and weaning practices through the ratios of stable isotopes of carbon and nitrogen in dentin and bone collagen in several Finnish populations. The postmedieval period is interesting from the perspective of childhood history, not only because of the multitude of funerary practices and other materials available through this research, but also for the opportunity to investigate the various aspects of childhood in longue durée. The 18th and 19th centuries are thought to have been when the modern perception of childhood as an "innocent and pure" phase in life emerged (Cunningham 1991). Studying the historical processes behind this phenomenon provides clearer understandings not only of historical perceptions of children and childhood, but also modern beliefs regarding childhood.

\section{Material Management and Preservation in Church Under-Floor Archaeology}

To preserve the resources located under these church floors, we have chosen non- or minimally intrusive methods. These include CT scanning of select coffins; microcomputed tomography $(\mu \mathrm{CT})$ scanning of textiles and samples from human remains; collecting samples from human remains for aDNA analysis (disease history) and isotope analysis (food consumption); collecting insect and plant samples; and collecting thread samples from textiles (sample length 5-10 $\mathrm{mm}$ of thread). Whereas sample collection is microdestructive, CT scanning and $\mu \mathrm{CT}$ scanning are nondestructive and nondisruptive to the remains or artifacts, but enable researchers to see textile structures through cross sections and view materials of different densities separately (textile, bone, metals, and wood are of different densities). These methods make it possible to see, for instance, where coffin nails are located and observe the tree-ring structure of the wood. With CT-scanning technology it is possible to create a 3-D model, which allows for analysis of materials beneath the surface layer without disturbing the burial. For example, it is possible to see whether the deceased was wearing socks without opening the coffin. $\mu \mathrm{CT}$ scanning makes it possible to see internal structures of textiles and below felted surfaces. The images reveal textile structures that may be examined thread by thread. However, as with any methodology, CT scanning has also its challenges. The CT-scanned objects are subject to radiation and impact the ability to use scanned materials for DNA sampling in the future. Additionally, CT scanning must be done at a hospital, and moving items introduces a number of logistical and ethical issues. Nevertheless, the coffins have been repositioned under church floors by parishioners for centuries, which challenges the stereotype of "peaceful rest" (Lipkin et al. 2018). Infant coffins were selected due to their small size and condition, as they were easily transportable to Oulu University Hospital. Rungius's coffin is large but in good condition, allowing it to be moved for research purposes.

For years the Church, Space and Memory Project has recorded the humidity and temperature levels under the floors as part of an ongoing effort to better understand these preserving microclimates. The data collected illuminate why some human remains mummified, define what conditions contribute to such excellent preservation, and address the current threat faced by a noted increase in decay and mold in these contexts. Some structural changes made inside the churches in recent years have negatively affected the conditions under floors; rising temperature and reduced air flow in the base floors of the churches have, in some cases, caused the mummified remains to mold visibly. Our aim is to help parishes protect the burials as they seek to correct the structural errors that resulted from updates made in the 1950s and 1970s, and to create suitable environments under floors in order to protect the cultural heritage. We are also able to observe postdepositional disturbances inside the burials through the identification of insect remains, evidence left behind by rodents and human activity, and by comparing the preservation today with observations made at the time of the inventories in the 1990s. 


\section{Balance between Researchers and Parishes}

Acquiring research permits, especially for sampling or removing the deceased for $\mathrm{CT}$ scanning, presents some practical and ethical challenges. No single Finnish authorizing body is responsible for issuing permits for such research. The Finnish Heritage Agency preserves, collects, studies, and displays items and artifacts that represent cultural heritage of national importance in Finland. The agency also grants archaeological research permits. The Antiquities Law (Muinaismuistolaki) (Finlex Data Bank 1963) protects ancient monuments and states that burials must be at least 100 years old or the active burial period must have ended at least 100 years ago to be under the purview of the Heritage Agency. However, as the deceased are beneath churches that are still in active use as part of their respective parishes, the Evangelical Lutheran Church of Finland considers them to be under the 1993 Church Law (Kirkkolaki) (Finlex Data Bank 1993), which highlights "reverence or piety," meaning respectful treatment of the deceased. The terms "ancient" and "in the care of parishes" are ambiguously described in the Antiquities Law, and, as a result, various stakeholders have diverse understandings of how to interpret the law.

In practice, developing personal contacts with the individual vicars, who have the authority in their respective parishes, has been the key to navigating these complicated situations. Explaining our aims and how the parishes can benefit from our research is essential. By engaging in sustained dialogue, the vicars at our partner churches understand that our scholarship is guided by clear research questions focused on better understanding the people of the past, rather than voyeuristic curiosity about death. Just as these relationships facilitate our research, they also require a certain amount of balancing the diverse attitudes in the parishes, and our research has accommodated community partners' conditions; for instance, not all the parishes are willing to permit CT scanning or sampling.

\section{Dignity and Respect for the Deceased}

In our projects, we emphasize certain principles that we think are essential to ethical, scientifically rigorous archaeological research. As researchers, we use the most nondestructive methods and take care of proper data management and storage, both while the projects are ongoing and after they finish. Because the remains are fragile, we also avoid unnecessary physical contact with the coffins, human remains, and textiles in situ under church floors. Ethical considerations have also influenced every phase of the research. Our research follows the international codes of ethics concerning archaeological research and the handling of human remains (World Archaeological Congress 1989; British Association of Biological Anthropology and Osteoarchaeology Working-Group for Ethics and Practice 2010).

As archaeologists, we are primarily interested in human stories and different aspects of humanity behind material culture, in this case the conceptions of death and how they are reproduced in material culture. While studying the human remains and their material culture through CT scans, photographs, or by the coffins, archaeologists deal with the interface between objectification of humans through chosen methods and subjectification in terms of studying humans as phenomena of humanity, life, and the nature/culture interrelationship (Barad 2007:205-212). Archaeologists need to find balance between objectification and subjectification in the interpretation of their data, and it is not always simple. Sian Anthony (2016:30) considers this bias in the context of revealing the identity of the recently deceased: naming the deceased in archaeological research is thought to give humanity to the excavated human remains, or, conversely, archaeological research is considered more respectful when it maintains individuals' anonymity and only considers remains as a part of a larger statistical analysis. Both of these views may be problematic. For some, studying burials may be, regardless of context or era, disrespectful, and names alone do little to restore their humanity. Human life is special, and the human remains and burial context reveal undeniable facts about human health and social history. However, treating human remains as only "statistical material" leads to distanced views of humanity and neglects individual histories that are important if the goal is to understand the past (Kaufmann and Rühli 2010).

In Europe it is not uncommon to publish images of mummified human remains in journals and monographs, and sometimes the captions include the names of these individuals; examples of published images with individuals' names include Jonsson (2009), Nyberg (2010), Grupa and Dudziński (2013), Colleter et al. (2016), and Karsten and Manhag (2017). When facing the dead in the field or during the analysis, 
archaeologists are always affected by their own mindsets, which are usually collective, according to the views of theoretical schools, research activities/ positions (field experience, bioanthropologist, university professor, etc.), as well as common research practice and perceptions of national societies or bureaus (Rajala 2016). The Finnish code of ethics for archaeologists (Suomen Arkeologinen Seura 2017) indicates that, "if the research material concerns identifiable human beings or their descendants, ... it should be done in a manner that individual persons are not identifiable without their permission. While publishing research results, identifiable persons should be treated respectfully."

Some of the human remains under Finnish church floors can be identified by name using the burial location and parish records, and occasionally the name of the deceased is on coffin plates or written inside the coffin lids. Foremost, we want to emphasize that, whether or not the human remains in question can be identified, they should all be treated with the same dignity regardless of their recovery contexts. We have chosen not to describe these identified burials in detail, reveal their exact locations under the church floors, and, most importantly, not publish facial pictures of their remains. These procedures still allow us to reproduce the life histories of the individuals. If not unethical, we see publishing facial pictures of human remains inconsiderate towards both the remains and the audience. Unless there is a scientific reason to publish faces, we find it important that photographic documentation of the human remains will be used for research purposes only. If the research is focused on taphonomy or reasons of mummification, it may be necessary to publish, for example, a contorted facial expression, but if the research is about burial traditions or material culture in general, there is no reason for such publishing. We find CT-scanned images of the face area less intrusive, and there are often scientific reasons to publish such images.

Since research on mummified human remains is relatively novel in Finland, minimal reference to the identities of the deceased has also been a safe choice. Although our research has generally been accepted with interest by the public, this has not always been the case, and a number of our choices are designed to help protect the relationship between parish and project. This was highlighted following the publishing of pictures of mummified human remains by a local newspaper (Oikarinen 2004), which was mistakenly connected to our research. The representatives of the local parish church council, a board responsible for controlling the activities, administration, buildings, and finances of the parish, felt that the published pictures would offend the members of the parish, as they were descendants of the deceased. By the time the project was aware of the situation, the damage had already been done, and the images are still accessible online.

Our approaches are also rooted in the customs established during the creation of the 1990s inventories and our discussions and experiences with the parish representatives and the public. The parishes are understandably reluctant to shock their members with pictures of their ancestors. We feel that with our choices we thus respect the current parish members and maintain the trust of the stakeholders involved in the processes of acquiring research permits. Vicar Rungius remains an exception to this policy, as his remains were already well-known and documented prior to our work, and numerous photographs of him are available online and in available literature. Every summer he is also visited by tourists from all over the world, although the parish does not allow visitors to photograph the remains.

\section{Stewarding the Past for the Future}

The success of these projects is based on both effective and positive outreach to the parishes and wider audience, as well as sharing knowledge between researchers and other research groups. We have found it important to present our research results at scientific conferences and are actively seeking new research partners to share this material (Lipkin and Ruhl 2016; Väre et al. 2018). We have actively offered our research data to students of all educational levels, in Finland and internationally, as material for undergraduate research, master's thesis projects, and doctoral dissertations.

In addition to research papers, our projects take responsibility for providing knowledge about the research and the results to a wider audience. Especially important is the local community, which feels kinship with the deceased. We offer easily understandable and accessible information about local social history for all audiences regardless of their age or background. Through our public outreach events and our project blog, we give the public audience the opportunity to engage with and react to our research. Workshops organized with schools have expanded local students' knowledge of both archaeology and multidisciplinary research methods, and 
promoted valuing the cultural environment surrounding their neighborhoods. The projects are also producing public exhibitions in collaboration with local regional museums about the tradition of under-floor church burials and the results of the projects.

Since the burials are at risk of decaying and vanishing in the future, recording and preserving them are integral to our goals. Expressing the uniqueness of the preservation of the under-floor church burials, their significance for the interpretations of past human life, and reproducing the past stories successfully for the audiences will ensure the willingness to preserve the burials instead of removing them during renovation projects. We hope the findings of the projects, such as the suitable humidity and environment for the continued preservation of the remains, will help the parishes in maintaining the burials intact into the future.

Acknowledgments: The authors are grateful to the Emil Aaltonen Foundation (Finland) and the Academy of Finland for funding this research.

Funding Open access funding provided by University of Oulu including Oulu University Hospital.

\section{Compliance with ethical standards}

Conflict of Interest The authors declare that they have no conflict of interest.

Open Access This article is licensed under a Creative Commons Attribution 4.0 International License, which permits use, sharing, adaptation, distribution and reproduction in any medium or format, as long as you give appropriate credit to the original author(s) and the source, provide a link to the Creative Commons licence, and indicate if changes were made. The images or other third party material in this article are included in the article's Creative Commons licence, unless indicated otherwise in a credit line to the material. If material is not included in the article's Creative Commons licence and your intended use is not permitted by statutory regulation or exceeds the permitted use, you will need to obtain permission directly from the copyright holder. To view a copy of this licence, visit http://creativecommons.org/licenses/by/4.0/.

\section{References}

Anthony, Sian

2016 Questions Raised in Excavating the Recent Dead. In Archaeologist and the Dead. Mortuary Archaeology in Contemporary Society, Howard Williams and Melanie Giles, editors, pp. 21-38. Oxford University Press, Oxford, UK.

Barad, Karen

2007 Meeting the Universe Halfway: Quantum Physics and the Entanglement of Matter and Meaning. Duke University Press, Durham, NC.

British Association of Biological Anthropology and Osteoarchaeology Working-Group for Ethics and Practice

2010 British Association of Biological Anthropology and Osteoarchaeology: Code of Ethics. British Association of Biological Anthropology and Osteoarchaeology <http://www.babao.org.uk/assets/ Uploads-to-Web/code-of-ethics.pdf $>$. Accessed 5 May 2019.

Cherryson, Annia Kristina

2018 Dressing for the Grave: The Archaeological Evidence for the Preparation and Presentation of the Corpse in Post-Medieval England. In The Oxford Handbook of the Archaeology of Death and Burial, Sarah Tarlow and Liv Nilsson Stutz, editors, pp. 37-55. Oxford University Press, Oxford, UK.

Colleter, Rozenn, Fabrice Dedouit, Sylvie Duchesne, FatimaZohra Mokrane, Véronique Gendrot, Patrice Gérard, Henri Dabernat, Éric Crubézy, and Norbert Telmon

2016 Procedures and Frequencies of Embalming and Heart Extractions in Modern Period in Brittany. Contribution to the Evolution of Ritual Funerary in Europe, 28 December. PLoS ONE 11(12). PLOS ONE <https://journals.plos.org/plosone/ article?id=10.1371/journal.pone.0167988>. Accessed 20 August 2020.

Cunningham, Hugh

1991 Children of the Poor: Representation of Childhood since the Seventeenth Century. Blackwell, Oxford, UK.

Finlex Data Bank

1963 Muinaismuistolaki (The Antiquities Law). Finlex Data Bank <https://www.finlex.fi/fi/laki/alkup/19 63/19630295>. Accessed 25 April 2019.

Finlex Data Bank

1993 Kirkkolaki (The Church Law), 26 November. Finlex Data Bank <https://www.finlex.fi/fi/ laki/ajantasa/1993/19931054?search\%5Btype\% 5D=pika\&search\%5Bpika\%5D=kirkkolaki $>$. Accessed 25 April 2019.

Grupa, Małgorzata, and Tomasz Dudziński

2013 Tajemnice szczuczyńskich krypt (Secrets of the Szczuczyn crypt). Towarzystwo Przyciól 9 PSK, Grajewo, Poland.

Hellemaa, Lahja-Irene, Anja Jussila, and Martti Parvio (editors) 1986 Näköispainos ja uudelleen ladottu laitos vuoden 1686 kirkkolain suomennoksesta (Facsimile and reprint of the Finnish translation of the 1686 Church Law). Suomen Kirjallisuuden Seuran Toimituksia 444. WSOY, Juva, Finland.

Hiekkanen, Markus

2003 Suomen kivikirkot keskiajalla (Finnish stone churches in the Middle Ages). Otava, Keuruu, Finland. 
Jonsson, Kristina

2009 Practices for the Living and the Dead. Medieval and Post-Reformation Burials in Scandinavia. Stockholm University, Stockholm Studies in Archaeology 50. Stockholm, Sweden.

Karonen, Petri

1999 Pohjoinen suurvalta: Ruotsi ja Suomi 15211809 (Northern great power: Sweden and Finland 1521-1809). WSOY, Helsinki, Finland.

Karsten, Per, and Andreas Manhag

2017 Peder Winstrup - historier kring en 1600talsmumie (Peder Winstrup - history around the 17th-century mummy). Lunds universitet, Historiska museet, Lund, Sweden.

Kaufmann, Ina Maria, and Frank Rühli

2010 Without 'Informed Consent'? Ethics and Ancient Mummy Research. Journal of Medical Ethics 36:608-613.

Laasonen, Pentti

1991 Suomen kirkon historia II, vuodet 1593-1808

(The history of the Finnish church II, years 1593-1808). WSOY, Porvoo, Finland.

Laitinen, Riitta

2016 Kirkkotilan hidas reformaatio: materiaaliset ja opilliset muutokset Turun tuomiokirkossa (The slow reformation of church space: Material and doctrinal changes in Turku Cathedral). In Pohjoinen reformaatio, Meri Heinonen and Marika Räsänen, editors, pp. 221-237. Turku Centre for Medieval and Early Modern Studies, Turku, Finland.

Lipkin, Sanna, and Erika Ruhl

2016 Postmedieval Finnish Textiles: A Transatlantic Collaboration. Society for Historical Archaeology Newsletter 49(4):20. onlinedigeditions.com <http:// onlinedigeditions.com/publication/?i=377537 $\& \mathrm{p}=\& \mathrm{pn}=>$. Accessed 5 October 2018.

Lipkin, Sanna, Tiina Väre, Titta Kallio-Seppä, Annemari Tranberg, Erika Ruhl, Sirpa Niinimäki, Juho-Antti Junno, Mikko Finnilä, and Jaakko Niinimäki

2018 Benefits of CT-scanning in Study of PostMedieval Funerary Items. Poster presented at the Society for American Archaeology conference, Washington, DC.

Meinander, Henrik

Suomen historia. Linjat, rakenteet ja käännekohdat. (History of Finland. Lines, structures, and watersheds). WSOY, Helsinki, Finland.

Modée, Reinhold Gustaf

1774 Utdrag utur alle ifrån 1764 års slut utkomne publique handlingar, placater, förordningar, resolutioner och publicationer. Attonde delen, til 1767 års slut (Excerpts of all public documents, placards, ordinances, resolutions, and publications from year-end 1764. Eighth part, until the end of the year 1767). Griefing, Stockholm, Sweden.
Modée, Reinhold Gustaf

1803 Utdrag utur alle ifrån år 1783 utkomne publique Handlingar, placater, förordningar, resolutioner och publicationer. Trettonde delen til 1786 års slut (Excerpts of all public documents, placards,ordinances, resolutions, and publications from year-end 1783. Thirteenth part, until the end of the year 1786). Kongl. Tryckeriet, Stockholm, Sweden.

Murtorinne, Eino

1992 Suomen kirkon historia III. Autonomian kausi 1809-1899 (The history of the church of Finland III. Time of autonomy 1809-1899). WSOY, Porvoo, Finland.

Mytum, Harold, and Laurie Burgess (editors)

2018 Death across Oceans: Archaeology of Coffins and Vaults in Britain, America, and Australia. Smithsonian Institution Scholarly Press, Washington, DC.

Núñez, Milton, Markku Niskanen, Marja-Leena Kortelainen, Juho-Antti Junno, Kirsti Paavola, Sirpa Niinimäki, and Mirette Modarress

2011 Finland. Introduction: A Brief History and Current State of Physical Anthropology in Finland. In The Routledge Handbook of Archaeological Human Remains and Legislation: An International Guide to Laws and Practice in the Excavation and Treatment of Archaeological Human Remains, Nicholas Márquez-Grant and Linda Fibiger, editors, pp. 138-149. Routledge, New York, NY.

Nyberg, Jenny

2010 A Peaceful Sleep and Heavenly Celebration for the Pure and Innocent. The Sensory Experience of Death during the Long Eighteenth Century. In Making Sense of Things: Archaeologies of Sensory Perception, Fredrik Fahlander and Anna Kjellström, editors, pp. 15-33. Stockholm University, Sweden.

Oikarinen, Marjo

2004 Muumioiden salattu elämä (The secret life of the mummies), 11 July. Kaleva <https://www.kaleva .fi/uutiset/kotimaa/muumioiden-salattu -elama/385425/>. Accessed 22 January 2019.

Paavola, Kirsti

1998 Kepeät mullat. Kirjallisiin ja esineellisiin lähteisiin perustuva tutkimus PohjoisPohjanmaan rannikon kirkkohaudoista (Light soils. Study of the church burials on the coast of northern Ostrobothnia based on written and material sources). Acta Universitatis Ouluensis B Humaniora 28. Oulu, Finland.

Parland-von Essen, Jessica

2010 Ammatti, Avioliitto ja Arvostus: Helsinkiläinen Eliitti 1740-1820 (Profession, marriage, and respect: Elite in Helsinki 1740-1820). Schildts, Helsinki, Finland.

Rajala, Ulla

2016 Separating the Emotions: Archaeological Mentalities in Central Italian Funerary 
Archaeology. In Archaeologists and the Dead. Mortuary Archaeology in Contemporary Society, Howard Williams and Melanie Giles, editors, pp. 68-96. Oxford University Press, Oxford, UK.

Renshaw, Layla, and Natasha Powers

2016 The Archaeology of Post-Medieval Death and Burial. Post-Medieval Archaeology 50(1):159177.

Salonen, Kirsi

2016

Rooma, Tukholma ja Turku. Reformaation ja muuttuva kirkollinen hallinto (Rome, Stockholm and Turku. The Reformation and changing ecclesiastical administration). In Pohjoinen reformaatio, Meri Heinonen and Marika Räsänen, editors, pp. 73-89. Turku Centre for Medieval and Early Modern Studies, Turku, Finland.

Suomen Arkeologinen Seura

2017 Hyvään tieteelliseen käytäntöön (TENK) pohjautuvat eettiset periaatteet suomalaisessa arkeologisessa toiminnassa. (Ethical principles in Finnish archaeological activities based on good scientific practice [TENK]). Suomen Arkeologinen Seura <www.sarks.fi/arkisto/eetti set_ohjeet.pdf $>$. Accessed 10 October 2018.

Tagesson, Göran

2015

The Human Body as Material Culture-Linköping Cathedral Churchyard in the Early Modern Period. In The Archaeology of Death in Post-Medieval Europe, Sarah Tarlow, editor, pp. 19-38. De Gruyter Open, Warsaw, Poland.

Tarlow, Sarah 2002

Bodies, Selves and Individuals: Introduction. In Thinking through the Body: Archaeologies of Corporeality, Yannis Hamilakis, Mark
Pluciennik, and Sarah Tarlow, editors, pp. 2327. Kluwer Academic/Plenum, New York, NY.

Tarlow, Sarah (editor) The Archaeology of Death in Post-Medieval
Europe. De Gruyter Open, Warsaw, Poland.

Tarlow, Sarah, and Liv Nilsson Stutz (editors)

2013 The Oxford Handbook of the Archaeology of Death and Burial. Oxford University Press, Oxford, UK.

Turpeinen, Oiva

1979 Fertility and Mortality in Finland since 1750. Population Studies 33(1):101-104.

Veit, Richard F., and Alasdair M. Brooks (editors)

2011 Perspectives from Historical Archaeology: Mortuary and Religious Sites. Society for Villstrand, Nils Erik Historical Archaeology, Germantown, MD.

2009 Riksdelen: Stormakt och rikssprängning 15601812 (The national part: Great power and national explosion 1560-1812). Svenska litteratursällskapet i Finland, Helsinki, Finland.

Väre, Tiina, Fracesco M. Galassi, Jaakko Niinimäki, and JuhoAntti Junno

2018 Potential Case of Gynecomastia in Mummified Remains of an Early Modern Period Northern Finnish Vicar. Clinical Anatomy 31(5):641644.

World Archaeological Congress

1989 The Vermillion Accord on Human Remains. Code of Ethics, World Archaeological Congress $<$ https://worldarch.org/code-of-ethics/>. Accessed 5 May 2019.

Publisher's Note Springer Nature remains neutral with regard to jurisdictional claims in published maps and institutional affiliations. 